\title{
The Charles B. Woods Fielding Collection
}

\author{
O M B R A K, J R. \\ and C URT A. Z I M A N K Y
}

Henry Fielding had been, before turning to fiction, one of the most active and innovative of English playwrights, leading to what (in the opinion of one recent scholar) might have been "a period of theatrical activity paralleling that of the Elizabethan stage." 1 But Fielding"s plays were too strong for the government to tolerate; the Licensing Act of 1737 closed Fielding's theatre and regulated the English drama into a century and a half of controlled mediocrity. Fielding turned to other work, and his novels-particularly Joseph Andrews and Tom Jones-have drawn so much scholarly attention that the plays have been almost ignored. Indeed, until very recently almost none of these plays was in print, ${ }^{2}$ and only one-The Tragedy of Tragedies-had appeared in a satisfactory scholarly edition. ${ }^{3}$ The plays of Fielding,

I The London Stage 1660-1800, Part 3: 1729-1747, ed. Arthur H. Scouten (Carbondale: Southern Illinois University Press, 1961), I, vi.

2 The following are the Fielding plays now in print:

The Author's Farce, ed. Charles B. Woods, University of Nebraska Press, 1966.

Tom Thumb and The Covent-Garden Tragedy, both in Burlesque Plays of the Eighteenth Century, ed. Simon Trussler, Oxford University Press, 1969.

The Tragedy of Tragedies, in British Dramatists from Dryden to Sheridan, ed. George H. Nettleton and Arthur E. Case, 2nd ed. revised by George Winchester Stone, Jr., Boston: Houghton Mifflin, 1969.

The Grub-Street Opera, ed. Edgar V. Roberts, University of Nebraska Press, 1968.

The Historical Register for the Year 1736, in Eighteenth Century Drama: Afterpieces, ed. Richard W. Bevis, Oxford University Press, 1970.

The Historical Register for the Year 1736 and Eurydice Hissed, ed. William W. Appleton, University of Nebraska Press, 1967.

It is worth noting that Fielding's more conventional comedies like The Miser and The Modern Husband are not represented; his most important political farce, Pasquin, is likewise unobtainable.

3 Ed. James T. Hillhouse, Yale University Press, 1918. 
highly unorthodox in their staging and highly topical, required intensive work.

This was the project that Professor Charles B. Woods set himself. Fielding's plays formed the subject of his Harvard dissertation in 1935, and a brief article in PMLA in 1937 gave a bare suggestion of how much could be done. ${ }^{4}$ His goal was an cdition, and, in the war years and their aftermath, that seemed hopelessly remote. In the late 1950's, however, The Wesleyan University Press agreed to sponsor a complete Fielding edition, with the three volumes of plays to be edited by Professor Woods. Though hindered by illness, he did complete much of the basic research, but in effect the opportunity had come too late. One play, The Author's Farce, was in near-final form so that, stripped of the technical apparatus prepared for the Wesleyan edition, it could appear in the popular Regents Restoration Drama Series of the University of Nebraska Press. After Professor Woods' death in February 1965, his papers and microfilms were placed at the disposal of the Wesleyan editors, and in time the microfilms-both those owned by Woods and those acquired by The University of Iowa for him-will be returned to Iowa for use with his basic Fielding collection. That collection has been acquired by The University of Iowa Libraries.

Bibliographical problems abound in Fielding works, parficularly in the hastily-published plays and the ephemeral tracts, and so it was on these items that Woods focused his collection. The major things-like a first edition of Tom Jones-were there, but the heart of the collection is in the plays. These books are for the most part working copies, and not all would appear to advantage in a display casc. Some are unbound, a few even disbound, some inelegantly cropped. But almost without exception the copies are free from defects or losses that would impair the books' usefulness for purposes of bibliographical description. Woods did not try to collect duplicates, but used his own copies as points of departure for comparison with other copies, either directly or on microfilm. This comparison is of some importance, for in Fielding's plays things are not always what they seem: there are two almost identical printings of The Author's Farce, either of which might be the first edition; The Grub-Strect Opera has a title-page date of 1731 but was probably printed nearer to 1760 ; the edition of The Historical Register listed as the first in Cross's bibliography turns out to be a Scottish piracy. ${ }^{5}$ This is probably only a small sampling of what can be found.

4 "Notes on Three of Fielding's Plays," PMLA, 52 (1937), 359-73.

5 The first two of these are discoveries by Woods. For The Author's Farce and 
The basic collection acquired by the University Library consists only of primary works; it is hoped that in time the University will acquire more of the eighteenth-century books that Professor Woods assembled around the Fielding collection. His collection meshes with the Fielding materials the Library already owns. There are thus now some duplications (e.g., the Library already had copies of Temple Beau and Pasquin) but more filling of gaps (the Woods collection has the first and fourth editions of Tom Jones, while the Library had a conflation of the first two editions and the third edition).

A memorial fund for Professor Woods has been established within The University of Iowa Foundation. A considerable portion of this fund will be used for further purchases to strengthen the Fielding collection.

No editions of Fielding's works which appeared after 1800 have been included in this handlist. The items are arranged in roughly the same order as they appear in the "Bibliography" in volume 3 of Wilbur L. Cross, The History of Henry Fielding (New Haven: Yale University Press; London: Humphrey Milford, Oxford Úniversity Press, 1918). When more exact information is available, such as that in The Rothschild Library: A Catalogue of the Collection of EighteenthCentury Books and Manuscripts formed by Lord Rothschild (Cambridge: Privately Printed at the University Press, 1954), it has been given. Occasionally additional information is given when there is some reason to believe that the Woods copy differs from that seen by Cross. Unfortunately the limitations of space have made it impossible to record signature collations, press figures, etc. in a systematic way.

\section{Fielding's Published Works}

Love in Several Masques. London: John Watts. 1728. [Cross, 290]

The Temple Beau. London: J. Watts. MDCCXXX. [Cross, 290]

The Author's Farce; and the Pleasures of the Town. London: J. Roberts. MDCCXXX. [Cross, 290-91; Woods, 01]6

The Author's Farce. The Second Edition. London: J. Watts. MDCCXXX.

The Author's Farce. The Third Edition. London: J. Watts, MDCCL. [Cross, 320]

Tom Thumb. London: J. Roberts. $1730 .{ }^{2} 2^{\circ}$ in half sheets. $\mathrm{II}^{1} \mathrm{~A}-\mathrm{B}^{6}$. This edition contains the preface, prologue and epilogue; it is not in Cross. This becomes The Tragedy of Tragedies. See below.]

The Historical Register, see the editions cited in note 2 above. Woods' memo on The Grub-Street Opera was first published by Edgar V. Roberts, "Mr. Seedo's London Career and His Work with Henry Fielding," Essays in English Neoclassicism in Memory of Charles B. Woods (Philological Quarterly), 45 [1966], 187, n. 20.

6 The Author's Farce, ed. Charles B. Woods, University of Nebraska Press, 1966, p. xi. 
The Coffee-House Politician; or, the Justice Caught in his own Trap. London: J. Watts. MDCCXXX. [Cross, 291-92; Masengill, III, a.7 This is the second edition of Rape upon Rape.]

The Tragedy of Tragedies; or the Life and Death of Tom Thumb the Great. London: J. Roberts. MDCCXXXI. [Cross, 292]

The Tragedy of Tragedies. London: ]. Roberts. MDCCXXXI. $\left[12^{\circ}\right.$ in half sheets. A-E $\mathbf{E}^{\mathbf{3}}$. Not in Cross]

The Tragedy of Tragedies. The Fourth Edition. London: J. Watts. MDCCLI.

The Tragedy of Tragedies. The Fifth Edition. London: A. Millar. MDCCLXV.

The Tragedy of Tragedies. The Sixth Edition. Edinburgh: James Reid. MDCCLXX.

The Tragedy of Tragedies. The Fifth Edition. London: T. Davies, T. Lowndes, W. Caslon, T. Becket, T. Cadell, G. Robinson, W. Nicoll, W. Woodfall, Wilson and Nichol, T. Evans in the Strand, and S. Bladon. MDCCLXXVI.

The Letter-Writers: Or, a New Way to Keep A Wife at Home. London: J. Roberts. MDCCXXXI. [Cross, 292]

The Welsh Opera: or, the Grey Mare the better Horse. London: Printed for E. Rayner, and sold by the Booksellers of London and Westminster. 1731. [Halftitle. This imprint not recorded by Cross. Revised and published as The GrubStreet Opera.]

The Lottery. London: J. Watts. MDCCXXXII. [Cross, 293-94]

The Lottery. The Second Edition. London: J. Watts. MDCCXXXII.

The Lottery. The Fifth Edition. London: A. Millar. MDCCLXI.

The Modern Husband. London: J. Watts. MDCCXXXII. [Press figures: 13-4, 30-7, 59-4]8

The Old Debauchees. London: Printed for J. W. And Sold by J. Roberts. MDCCXXXII. [Cross, 295. Reprinted as The Debauchees: or, The Jesuit Caught. See below.]

The Covent-Garden Tragedy. London: Printed for J. Watts, and Sold by J. Roberts. MDCCXXXII. [Cross, 295]

The Mock Doctor: or The Dumb Lady Cur'd. London: J. Watts. MDCCXXXII. [Cross, 296]

The Mock Doctor: or The Dumb Lady Cur'd. The Second Edition. London: J. Watts. MDCCXXXII.

The Mock Doctor: or, The Dumb Lady Cur'd. A New Edition. London: Printed for T. Caslon, T. Lowndes, T. Davies, Wilson and Nicholl, T. Becket, G. Kearsley, W. Griffin, S. Bladon, T. Cadell, and W. Woodfall. MDCCLXXI.

The Miser. London: J. Watts. MDCCXXXIII. [Cross, 297] ${ }^{9}$

The Miser. The Second Edition. London: J. Watts. MDCCXLIV.

The Miser. The Fourth Edition. London: A. Millar. MDCCLXI.

The Miser. . . To which is prefix'd the Life of the Author. Edinburgh: Martin \& Witherspoon. MDCCLXXI.

The Miser. Bell's Edition. London: Printed for John Bell and C. Etherington at York. MDCCLXXVI.

7 Jeanne Addison Masengill, "Variant Forms of Fielding's Coffee-House Politician," Studies in Bibliography, 5 (1953), 178-83.

8 D. F. Foxon, "Fielding's The Modern Husband, 1732," Book Collector, 5 (1956), 76-77; see also William B. Todd, ibid., p. 276.

9 "And Sold by Richafo Werlington at . . ." has been added under the imprint. The remainder of this additional imprint has been trimmed. 
The Intriguing Chambermaid. London: J. Watts. MDCCL.

Don Quixote in England. London: J. Watts. MDCCLIV.

Don Quixote in England. London: J. Wenman. MDCCLXXVII.

An Old Man taught Wisdom; or, the Virgin Unmask'd. London: John Watts. MDCCXXXV. [Cross, 298]

An Old Man Taught Wisdom, or, the Virgin Unmask'd. The Fourth Edition. London: J. Watts. MDCCXLIX.

An Old Man Taught Wisdom; or, the Virgin Unmask'd. The Seventh Edition. London: Printed for the Proprietor. MDCCLXX.

The Virgin Unmasked. London: Printed for T. Payne and Son, J. Nichols, G. G. J. and J. Robinson, T. Cadell, J. Murray, G. Nicol, S. Bladon, W. Lowndes, W. Nicoll, W. Fox, and D. Ogilvy. M.DCC.LXXXVI.

The Virgin Unmasked; A Musical Entertainment. By Henry Fielding, Esq. Taken from the Manager's Book at the Theatre Royal, Drury-Lane. London: Printed by R. Butters, n.d.

Pasquin. London: J. Watts. MDCCXXXVI. [Cross, 290; Rothschild, 840]

Pasquin. London: J. Watts. MDCCXXXVI. [ $8^{\circ}$ in half sheets. A4 B-H4. This edition has the title in black; it is not in Cross.]

Pasquin. The Second Edition. London: J. Watts. MDCCXL.

The Historical Register, For the Year 1736 ... To which is added . . Eurydice Hiss'd, or, A Word to the Wise. London: J. Roberts, n.d. [Cross, 301. $A^{8}$ B-D8. This edition is called the second by Cross, but is almost certainly the first. His first edition seems to be a piracy.]

The Historical Register, For the Year 1736. . . To which is added ... Eurydice Hiss'd. Dublin: Printed by S. Powell for G. Risk, G. Ewing and W. Smith, 1737.

The Historical Register, For the Year 1736. . . To which is added . . E Eurydice Hiss'd. London: J. Watts. 1741.

Of True Greatness. An Epistle to The Right Honourable George Dodington, Esq. London: C. Corbet. 1741. [Cross, 302-03; Rothschild, 841; fragment: lacks last two leaves.]

The Opposition. A Vision. London: T. Cooper. 1742. [Cross, 305]

The History of the Adventures of Joseph Andrews. The Second Edition. London: A. Millar. M.DCC.XLII. [Cross, 305-06; Battestin, 383-84]10

The History of the Adventures of Joseph Andrews. The Fourth Edition. London: A. Millar. MDCC.XLIX.

The History of the Adventures of Joseph Andrews. Dublin: Printed by S. Powell, For G. Ewing, W. Smith, and G. Faulkner. MDCCXIII.

Plutus, the God of Riches. London: T. Waller. MDCCXLII. [Cross, 307]

The Wedding-Day. London: A. Millar. MDCCXLIII. [Cross, 308; Press figures: 8-3, 10-4, 27-5, 37-2, 46-3, 55-3, 64-2, 70-2, 80-1, 83-1]

Miscellanies. In Three Volumes. London: Printed for the Author: And sold by A. Millar. MDCCXLIII. [Cross, 308-09; Eddy, first edition, first state] 11

The Charge of the Jury: or, the Sum of Evidence, on the Trial of A.B.C.D. and E. F. London: M. Cooper. 1745. [Not in Cross]

The Debauchees: or, the Jesuit Caught. London: Printed by and for J. Watts; and Sold by him .... and by W. Reeve. MDCCXLVI.

10 Joseph Andrews, ed. Martin C. Battestin, Wesleyan University Press, 1967.

11 Donald D. Eddy, "The Printing of Fielding's Miscellanies (1743)," Studies in Bibliography, 15 (1962), 247-56. 
The Debauchees: or, the Jesuit Caught. The Third Edition. London: J. Watts. MDCCL.

A Dialogue between the Devil, the Pope, and the Pretender. London: $\mathrm{M}$. Cooper. MDCCXLV. [Cross, 312]

The Female Husband: or, the Surprising History of Mrs. Mary, alias Mr. George Hamilton. London: M. Cooper. 1746. [Not in Cross]

A Dialogue between a Gentleman of London, Agent for two Court Candidates, and an Honest Alderman Of the Country Party. London: M. Cooper. 1747. [Cross, 315; Todd, state b]12

A Proper Answer to a Late Scurrilous Libel. Dublin: Printed by S. Powell, For G. Faulkner and A. Bradley. MDCCXLVIII.

The History of Tom Jones, A Foundling. In Six Volumes. London: A. Millar. MDCCXLIX. [Cross, 316-17; Rothschild, 850]

The History of Tom Jones, A Foundling. In Four Volımes. London: A. Millar. MDCCXLIX. [Cross, 317; Third Edition]

A Charge Delivered to the Grand Jury. London: A. Millar, 1749. [Cross, 319]

An Enquiry Into the Causes of the late Increase of Robbers. London: A. Millar. M.DCC.LI. [Cross, 320]

An Enquiry Into the Causes of the late Increase of Robbers. The Second Edition. London: A. Millar. MDCCLI.

Amelia. London: A. Millar. M.DCC.LII. [Cross, 321-22; Rothschild, 853]13

Examples of the Interposition of Providence in the Detection and Punishment of Murder. Dublin: James Hoey, James Esdall, and Samuel Price. MDCCLII.

A Proposal for Making an Effectual Provision for the Poor. London: A. Millar. MDCCLIII. [Cross, 325; Rothschild, 854; folding plan in photostat] -

A Clear State of the Case of Elizabeth Canning. London: A. Millar. M.DCC.LIII. [Cross, 325]

The Life of Mr. Jonathan Wild the Great. A New Edition. London: A. Millar. MDCCLIV. [Cross, 325-26; Rothschild, 856]

The Journal of a Voyage to Lisbon. London: A Millar. MDCCLV. [First edition: Cross, 326; Rothschild, 857]

The Journal of a Voyage to Lisbon. London: A. Millar. MDCCLV. [Second Edition]

The Fathers: or, The Good-Natur'd Man. London: T. Cadell. M.DCC.LXXVIII.

\section{II \\ Works to which Fielding Contributed}

Orestes: A Dramatic Opera. Written by Mr. Theobald. London: John Watts. MDCCXXXI. [Not in Cross] Epilogue by Fielding.

The Modish Couple. A Comedy. London: J. Watts. MDCCXXXII. [Cross, 294] The play is by Charles Bodens; Epilogue by Fielding.

Caelia: or, The Perjur'd Lover. London: I. Watts. MDCCXXXIII. [Cross, 296] Play by Charles Johnson; Epilogue by Fielding.

Fatal Curiosity; A True Tragedy in Three Acts. By Mr. Lillo. London: John Gray. MDCCXXXVII. [Cross, 300] Prologue by Fielding.

12 William B. Todd, "Three Notes on Fielding," Papers of the Bibliographical Society of America, 47 (1953), 71-72.

13 Ibid., pp. 72-75. 
Common Sense: or, The Englishman's Journal. London: J. Purser and G. Hawkins, MDCCXXXVIII. [Cross, 301] Contains at least one essay by Fielding.

The Champion. Vol. I. London: J. Huggonson. MDCCXLI. Vol. II. The Second Edition. London: H. Chappelle. M.DCC.XLIII. [Cross, 304-05]

The Adventures of David Simple. By a Lady. In Two Volumes. The Second Edition, Revised and Corrected. With a Preface by Henry Fielding, Esq; London: A. Millar. M.DCC.XLIV. [Cross, 309]

Familiar Letters between the Principal Characters in David Simple, And Some Others. To which is added, A Vision. By the Author of David Simple. London: Printed for the Author: And Sold by A. Millar. MDCCXLVII. [Cross, 314] Preface and five letters by Fielding.

\section{III}

\section{Wonks Associated with Fielding}

An Apology for the Life of Mr. T ...... C ..., Commedian Supposed to be written by Himself. London: J. Mechell. 1740. [Cross, 337; Todd, edition B.14 Often attributed to Fielding; certainly not by T. Cibber.]

The Causidicade. A Panegyri-Satiri-Serio-Comic-Dramatical Poem. On the Strange Resignation, and Stranger-Promotion. By Porcupinus Pelagius. London: M. Cooper. 1743. [Cross, 343. Erroneously ascribed to Fielding.]

[Eliza Haywood and William Hatchett?] The Opera of Operas; or, Tom Thumb the Great. Alter'd from the Life and Death of Tom Thumb the Great. London: William Rayner. MDCCXXXIII. [Cross, 350-51]

An Historical View of the Principles, Characters, Persons, dc. of the Political Writers in Great Britain. London: W. Webb. MDCCXL. [Contains a sketch of Fielding's early career.]

[William Hodson] The Adventures of a Night. London: T. Evans. MDCCLXXXIII. [Adaptation of The Coffee-House Politician.]

A Letter to a Noble Lord, To whom alone it Belongs. Occasioned by a Representation at the Theatre Royal in Drury-Lane, of a Farce, called Miss Lucy in Town. London: T. Cooper. MDCCXLII. [Cross, 343. Attributed to Fielding.]

[James Miller] Seasonable Reproof. A Satire. London: L. Gilliver. MDCCXXXV. [Contains an early reference to Fielding as playwright.]

[Pritchard] The Fall of Phaeton. London: R. Turbut. MDCCXXXVI. [Butt of Tumble-Down Dick.]

Joseph Reed. Tom Jones, A Comic Opera. London: Printed for Becket and DeHondt; and Richardson and Urquhart. MDCCLXIX. [Cross, 353]

Remarks upon the Account of the Conduct of a Certain Duchess. London: T. Cooper. MDCCXLII. [The pamphlet to which Fielding replied in A Full Vindication of the Duchess Dowager of Marlborough.]

14 Ibid., pp. 70-71. 


\section{T H E}

\section{Intriguing Chambermaid.}

$\mathbf{A}$

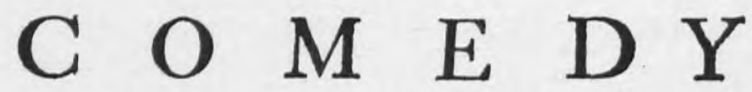 \\ Of TWO ACTS.}

As it is Acted at the

\section{Theatre-Royal in Drury-Lane,} By His M A J E S T Y's Servants,

Taken from the French of R E G N A R D,

By $H E N R T$ FIELDING, Efq;

Majores nufquam ronchi; juvenéfque fenéfque Et pueri nafum Rbinocerotis babent. Martial.

$$
L O N D O N:
$$

Printed for J. WA T $\mathbf{S}$ at the Printing-Office in Wild-Court near Lincoln's-Inn Fields.

\section{DCC L.}

[Price One Shilling.]

Title page of Henry Fielding's comedy The Intriguing Chambermaid, 1750, from the Charles B. Woods Collection. 


\section{A $\mathrm{N}$}

\section{E N Q U I R Y}

Into the CAUSES of the late

\section{Increafe of Robbers, $\Xi^{\circ} c$.}

W I T H SOME

PROPOSALS for Remedying this GROWING EVIL.

I $\mathrm{N}$ W $\mathrm{HICH}$

The Prefent Reigning VICES are impartially expofed; and the LAws that relate to the Provifion for the Poor, and to the Punimment of FeLONs are largely and freely examined.

Non jam funt mediocres bominum libidines, non bumane audacie ac tolerande. Nibil cogitant nific cadem, nifi incendia, niji rapinas. $C_{1}$. in Catil. $2^{d_{2}}$

\section{By HENRY FIELDING, Efq;}

Barrifter at Law, and one of His Majelty's Jultices of the Peace for the County of Middlefex, and for the City and Liberty. of Weftminfter.

\section{The SECOND EDITION.}

\section{O N D O N :}

Printed for A. MILLAR, oppofite to KatharineStreet, in the Strand. MDCCLI.

Fielding was not only a novelist and a dramatist but also a justice of the peace. Above is the title page from one of his contributions to the literature of crime, An Enquiry into the Causes of the Late Increase of Robbers, 1751. 